will be required yearly to feed the circulation of the cold bottom water in the North Polar basin.

This brief outline of the contents of this interesting memoir will give some idea of the thoroughness of its scientific methods and the great labour that has been bestowed upon them.

\section{THE COMMEMORATION OF LORD LISTER'S EIGHTIETH BIRTHDAY.}

THE eightieth anniversary of the birthdar of Lord Lister occurred on Friday last, April 5. Many scientific men have had the good fortune to discover the causation of phenomena of immediate practical importance, but to few have been vouchsafed the privilege of seeing the results of their discoveries become in a few years of such enormous benefit to their fellow men as those of Joseph Lister. No man alive has by a single discovery conferred upon the whole of mankind a greater boon than did the surgeon who discovered the causation of the direful but not unusual sequelae of a surcrical operation, viz. suppuration, septicæmia, secondary hæmorrhage, erysipelas, and hospital gangrene, and who showed that by preventing the access of bacteria to wounds all these diseases could be avoided.

It is just f irty years since the first papers of Lord Lister dealing with his discoveries were published in the Lancet. How the best skill of the surgeon was baffled by these wound infections and the whole development of surgery prevented may be realised by a quotation from a leading article in the Lancet written at the time of the publication of one of Lister's earliest papers in 1867 .

The mortality of compound fractures, of amputations and operations and of lithotomy in our larger hospitals, both provincial and metropolitan, is something frightful. And the occurrence of death with symptoms of bloodpoisoning is, unfortunately, not confined to cases of serious operation, but happens ever and anon in operations in themselves slight. The risk of blood-poisoning is indeed now the one great opprobrium of surgery. There is no limit to the operative feats of surgeons, but there is a miserable and serious risk in every case, especially in hospitals, of the occurrence of fatal after-consequences, against which-until now at least-we have had little or no power of resistance.

The story of the discovery of antiseptic surcery was briefly told by Lord Lister himself in the third Huxley lecture delivered in Iaoo. In this lecture Lord Lister explained how by the time he became a house-surgeon at University College he was already cndowed with a love of physiolory and a first-rate microscope. The former he owed to the inspiration of Prof. Sharper and the latter to his father, who did so much to raise the compound microscope from little better than a tov to the powerful engine for investigation which it then was. As a young surgeon his attention was immediately turned to the study of those scourges of surcery, suppuration, præmia, and hospital gangrene. During the next ten vears he made a number of investigations upon the carly stages of inflammation and the healing of wounds. $\mathrm{He}$ was early led to the conclusion that suppuration and septic diseases were due to a poison acting locally, and again and again he searched with the aid of the microscope the discharges from wounds in the hope of discovering some materies morbi of an organised kind.

The idea that wound infections were of parasitic origin, although the parasite escaped detection, was early in his mind, so that when the epoch-making discoveries of Pasteur on the nature of fermentation and putrefaction were published, Lister was prepared to appreciate the analogy between these phenomena and those of wound infection. Guided by this analogy, he devised methods to prevent the entrance of germs to wounds, and was immediately successful in obviating the evil effects hitherto so generally attendant upon the simplest operation.

The actual methods employed have undergone some modifications and simplification in accordance with the development of knowledge during the last fifty rears, but the principle to protect wounds from the access of germs "by means which shall disturb the tissues as little as is consistent with the attainment of the essential object" retains its full value at the present time.

I ord Lister has been the recipient of many honours, bestowed upon him by every civilised community, but it was widely desired that his eightieth birthday should be suitably commemorated. It was considered by some of his admirers that this could best be done by the re-publication, by subscription, of his collected work in suitable form. Invitations were accordingly issued to a number of scientific and medical men, both at home and abroad, to form themselves into a committee for this purpose. The invitations have met with a warm response, and the committee may be described as an international one.

A meeting of this committee took place on Thursday, April 4, at the Royal College of Surgeons, which was presided over by Mr. Henry Morris, the president of the college. It was unanimously resolved to ask Lord Lister to allow the committee to republish his scientific papers, and a small editorial committee was chosen to carry out this object. The following letter was sent to Lord Lister from the committee :- -

DEAR L.ORI IISTER,

A desire having been widely felt that the eightieth anniversary of your birthday should be marked in some special manner, a committee of your professional brethren both at home and abroad was formed to consider in what way this could best be done.

This committee met to-day at the Royal College of Surgeons, when it was unanimously resolved to ask you to allow them to commemorate the occasion by collecting and publishing your various scientific papers in book form. In anticipation of your acquiescence, an editorial committce was appointed to carry out such publication.

At the same time, those present at the meeting wished to convey to you their warmest congratulations on this occasion, and gratefully to acknowledge the debt which the medical profession, and, indeed, the whole world, owe to you for the work which you have done. That you have lived to see such enormous advances in surgery and medicine flow from your work must be a source of great gratification to you, and the committce hope that you may be spared to see still many further advances follow therefrom.

\section{I remain, dear Lord Lister,}

\section{Yours sincerely.}

(Signed) Hy. MORris.

President, Roval College of Surgeons, Chairman.

Lord Lister replied to the letter as follows:-

DFAR Mr. Morris,

I dulv received your letter yesterday informing me of the decision of the general committee to ask me to allow them to commemorate the occasion of my eightieth birthday br collecting and publishing my various scientific papers in book form.

This proposal is almost overwhelming in its kindness, and I expressed to the deputation which met here in the morning my profound sense of gratitude. This surpassingly generous offer is extremely gratifying to me.

\section{Believe me,}

Very sincerely yours,

(Signed) LIsTer. 
It is proposed to issue the collected papers in two quarto volumes of about 450 pages each. The volumes will contain a portrait of Lord Lister, and will be prefaced by a short account of the development of Lister's ideas and work and their relation to the growth of knowledge of infectious processes. They will be published at a subscription price of one guinea for the two volumes.

\section{NOTES.}

Sir JAMEs DEwar has been appointed a corresponding member of the Royal Academy of Sciences, Denmark.

THE U.S. Congress has voted 20,oool. for the erection of a monument to Christopher Columbus at Washington.

Prof. S. P. Thompson, F.R.S., has been elected a member of the Athenæum Club under the provisions of the rule which empowers the annual election by the committee of three persons "of distinguished eminence in science, literature, the arts, or for public services."

Mr. J. de Graaf Hunter, assistant in the physics department of the National Physical Laboratory, has been nominated by the India Office to the post of mathematical expert to the Survey of India.

THE monument erected by subscription in the garden of the Paris Institut national agronomique to Eugene Risler, the director of the institute from 1879 to 1900 , was unveiled by M. Ruau, the French Minister of Agriculture, on March 24.

THE British Medical Journal states that a laboratory for the study of human nutrition is to be built by the Carnegie Institute of Washington on a site adjacent to the Harvard Medical School. The work will be under the direction of Prof. F. G. Benedict, of Wesleyan University.

IN many places the rainfall measured already this month is greatly in excess of the aggregate measurement for the whole of March. On the night of April 6-7 there was a somewhat heavy fall of snow over the south of England, and at Warlingham, in Surrey, the ground was covered to the depth of 6 inches. In London, snow fell for some time in the early morning of Sunday, April 7, and the rainfall as yet this month already exceeds an inch. Thunderstorms have also occurred in different parts of the country. Notwithstanding that the aggregate rainfall at Greenwich for the first three months of the year was deficient by $\mathrm{r} .63$ inches, the total for the six winter months, October-March, was 0.75 inch in excess of the average for the past sixty years.

THE earthquake at Bitlis on March 29, briefly recorded in last week's NATURE, appears to have been of unusual severity, and was registered by seismographs at several distant stations. The earthquake occurred at ro a.m. on March 29, no fewer than fourteen severe shocks being felt on that day. Shocks stronger than the first were felt at Bitlis all night on March $3 \mathrm{r}$, resulting in fresh casualties and further destruction of houses. Violent shocks of earthquake were felt on April 2 in the island of San Miguel, Azores, particularly in the town of Villa Franca, which was formerly destroyed by earthquake.

THE two Royal medals of the Royal Geographical Society have been awarded, with the King's approval, to Dr. Francisco Moreno, who for more than twenty years has been personally occupied in the work of South American exploration, and Captain Roald Amundsen, the
Norwegian explorer, who recently completed the Northwest Passage for the first time in a ship, and made observations in the neighbourhood of the North Magnetic Pole. The Murchison bequest of the society has been awarded to Captain G. E. Smith, for his various surveys in British East Africa; the Gill memorial to Mr. C. Raymond Beazley, for his work in three volumes on "The Dawn of Modern Geography"; the Back bequest to Mr. C. E. Moss, for his researches on the geographical distribution of vegetation in England; and the Cuthbert Peek fund to Major C. W. Gwynn, C.M.G., R.E., for the geographical and cartographical work carried out by him in the Blue Nile region and on the proposed SudanAbyssinian frontier.

To the long list of eminent men of science that have lately bcen lost to France by death must be added the name of Colonel Laussedat, for many years the director of the Conservatoire des Arts et Métiers. More than sixty years ago he began his public career in the Ecole Polytechnique, and his long life was one of successful achievement. He served his country both in the field and in the study. During the siege of Paris he had charge of the optical contrivances for maintaining communications with the outside world, and later, at the close of the war, he was a member of the commission for arranging the new frontiers of the country. Besides filling the office of professor of geodesy, he was at different times member of many committees and numerous commissions, where his experience, knowledge, and ingenuity were gratefully acknowledged. But it is in the department of photography and in its applications to scientific purposes that he will be longest remembered. If he did not originate the application of photography to surveying and photogrammetric inquiries, he so encouraged its employment, improved its methods, and demonstrated its usefulness that he won for it a foremost place in the training of every modern topographer. Colonel Laussedat was a member of the French Academy and of many learned societies in his own and other countries.

As previousiy announced, the annual meeting of the Iron and Steel Institute will be held on May 9 and 10. At the opening meeting, the retiring president, Mr. R. A. Hadfield, will induct into the chair the president-elect, Sir Hugh Bell, Bart., the Bessemer gold medal for 1907 will be presented to Mr. J. A. Brinell (Stockholm), and the president will deliver his inaugural address. Among the papers to be submitted on May 9 and ro are the following:-The use of steam in gas-producer practice, Prof. W. A. Bone, F.R.S., and R. V. Wheeler; the influence of process of manufacture on some of the properties of steel, F. W. Harbord; the ageing of mild steel, C. E. Stromever; carbon-tungsten steels, T. Swinden; the nomenclature of iron and steel, report of a committee of the International Association for Testing Materials. Reports on research work carried out during the past year will be submitted by C. A. F. Benedicks (Sweden), O. Stutzer (Germany), E. F. Law (London), E. Hess (United States), P. Breuil (Paris), H. C. Boynton (United States), L. Guillet (France), W. H. Hatfield (Sheffield), A. Campion (Glasgow), E. G. L. Roberts (London), E. A. Wraight (London), and W. Rosenhain (Teddington), Carnegie research scholars. The annual dinner of the institute will be held in the Grand Hall of the Hotel Cecil on May 10, under the presidency of Sir Hugh Bell, Bart. The council has accepted an invitation to hold the autumn meeting of the institute in Vienna on September. 23-25. After the meeting there will be alternative excursions to NO. I 954, VOL. 75] 